\title{
PERCEPTION REGARDING SWINE FLU AMONG SCHOOL TEACHER IN INARUWA MUNICIPALITY OF EASTERN NEPAL
}

\author{
Uprety $S^{1^{*}}$, Limbu $N P M^{2}$, Poudel $M^{3}$, Ghimire $A^{4}$, Khanal $V K^{1}$, Baral $D D^{5}$
}

\section{Affiliation}

1. Associate Professor, School of Public Health and Community Medicine, BPKIHS, Dharan

2. Lecturer, Department of Community Health, Patan Academy of Health Sciences, Lalitpur

3. Additional Professor, Department of General Practice and Emergency Medicine, BPKIHS, Dharan

4. Professor, School of Public Health and Community Medicine, BPKIHS, Dharan

5. Assistant Professor, School of Public Health and Community Medicine, BPKIHS, Dharan

\section{ARTICLE INFO}

Article History

Received : 06 February, 2017

Accepted : 18July, 2017

Published : 30 August, 2017

(C) Authors retain copyright and grant the journal right of first publication with the work simultaneously licensed under Creative Commons Attribution License CC - BY 4.0 that allows others to share the work with an acknowledgment of the work's authorship and initial publication in this journal.

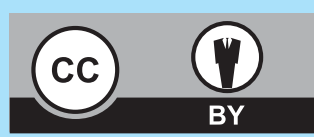

ORA 22

\section{* Corresponding Author}

Dr Samyog Uprety

Associate Professor

School of Public Health and Community Medicine

B. P. Koirala Institute of Health Sciences, Dharan, Nepal Email: samyog.uprety@bpkihs.edu

\section{Citation}

Uprety S, Limbu NPM, Poudel M, Ghimire A, Khanal VK, Baral DD. Perception Regarding Swine Flu Among School Teacher in Inaruwa Municipality of Eastern Nepal. BJHS 2017;2 (2)3 : 150-155

\section{ABSTRACT \\ Introduction}

Swine flu is an acute respiratory viral disease, caused by a strain of the influenza type A virus known as H1N1. Currently swine flu is spreading rapidly in India with a regular threat of it being spread to Nepal owing to the open borders.

\section{Objective}

The objective of this study was to assess the knowledge, attitude and practice on different aspects of Swine Flu.

\section{Methodology}

This is cross-sectional study conducted in Inaruwa municipality of Sunsari district from $1^{\text {st }}$ March to $10^{\text {th }}$ April, 2015. A total of 31 schools ( 21 private and 10 public) were identified in the municipality out of which 16 were randomly chosen for the study.

\section{Results}

Total sample size was 260 school teachers. Majority of the respondents belong to the age group 30-39 years, about $72 \%$ were male and $86 \%$ thought that it is a preventable disease. It was observed that females had a better attitude towards preventive measures of swine flu as compared to the males $(p<0.023)$, but males had better practices as compared to the females $(p<0.001)$.

\section{Conclusion}

The prevention practice for swine flu was not adequate. Despite having acceptable knowledge and attitude, positive practices needs to be encouraged. The teachers should be well informed about the earliest appearing symptoms of swine flu. So that they can closely monitor the students and can recommend the students for medical checkup on appearance of the symptoms.

\section{KEYWORDS}

Attitude, Nepal, Sunsari, swine flu 


\section{INTRODUCTION}

Swine flu is an acute respiratory viral disease, caused by a strain of the influenza type A virus known as $\mathrm{H} 1 \mathrm{~N} 1$, where $\mathrm{H}$ and $\mathrm{N}$ stand for two surface proteins of the virus. ${ }^{1}$ The illness is generally mild except in people in high risk groups as pregnant women and people with medical conditions like infection with other influenza viruses. ${ }^{2}$ Swine flu was reported in Mexico and spread over the world. The union agency reported more than 15,000 cases of swine flu in the globe. ${ }^{3}$ The Mexico had second highest number of infections nearly 5000 behind the united states of America with nearly 8000 cases. $^{3}$ Worldwide there was more than 375, 000 laboratory confirmed cases of pandemic influenza H1N1 in 2009 and thousands deaths reported to world health organisation (WHO). ${ }^{4}$

According to Rubin GJ et al regarding public perceptions about swine flu, respondents have perception that swine flu is severe, that the risk of catching is high, that the outbreak will continue for a long time. ${ }^{5}$ In another study by Joseph TF et al about widespread public misconception in the early phase of the H1N1 influenza epidemic done in Hongkong China, it was seen that public did not perceive a high likelihood of having a local H1N1 outbreak, nor did they regard $\mathrm{H} 1 \mathrm{~N} 1$ as a threatening diseases. ${ }^{6} \mathrm{~A}$ study done by Akan $\mathrm{H}$ et al in Turkey about the knowledge and attitudes among the university students toward pandemic influenza showed that the participants had enough knowledge about H1N1 pandemic, about the disease there were still gaps and confusion in some areas and main information source was mass media.' Nepal has open borders with neighboring countries specially with India so has always threat of spreading Swine flu. Out of the 300 samples collected from suspected cases across the country, a total of 42 patients have been tested positive for H1N1, as of $1^{\text {st }}$ March $2015 .{ }^{8}$ Thus, awareness is needed for its effective prevention. This study was conducted, keeping school teachers as our target population, as they are the foci for knowledge and can give the information regarding swine flu to the children.

\section{METHODOLOGY}

A cross-sectional study was conducted in Inaruwa Municipality, Eastern Nepal among school teachers of both government and private schools from $1^{\text {st }}$ March to $10^{\text {th }}$ April 2015. A total of 31 schools, including 21 private and 10 public were identified in the municipality, out of which 16 were randomly chosen for the study. Among 16 schools, 8 were public schools and 8 were private. For the sample size calculation, the information of a study conducted by Singh $A B$ et al in India was considered where the proportion of knowledge of swine flu among school teachers was about $60 \%$ with $95 \%$ confidence interval and $80 \%$ power, total sample size was 260 school teachers. ${ }^{9}$ Knowledge about the disease, mode of transmission, source of infection, routes of transmission, attitudes and perceptions of the disease were asked and its communicability, governmental efforts to combat it, ways of prevention were also studied. Each participant was asked to report the precautionary measures that $s /$ he has been using during the epidemic to prevent infection, maintaining personal hygiene extra care be taken for suspected case. Data collection was done via direct faceto-face interview using semi-structured questionnaire at school premises after taking permission from the headteacher and obtaining informed consent with respective teachers (All the school teachers were included in the study till the sample size was fulfill), prior study pretesting was done in $10 \%$ sample in Dharan, reliability test was performed and $60 \%$ cut off value was establish, using questions directed at accessing knowledge, attitude, practices, and demographic variables. Regarding knowledge, attitude and practices 41 , 11 and 62 score was made respectively and $60 \%$ cut of value was taken for acceptable limit so 25 (24.6 in knowledge); 7 (6.6 in attitude) and 38 (37.2 in practices) were the lower value considered respectively. Data was entered in Microsoft Excel 2007 and analysed using SPSS 11.5 version. Descriptive statistics as percentage, proportion, mean, standard deviation, were calculated along with graphical and tabular presentation. As a part of inferential statistics, correlation between the demographic variables and knowledge, attitude and practices, and one-way ANOVA test for the group variables was applied to find out the significant association at $95 \%$ confidence interval.

\section{RESULTS}

Table 1 shows the socio-demographic profile of the study population, in which majority were from $30-39$ years of age followed by 20-29 years, male population were predominant than female and majority were Hindu by religion. Similarly, while observing by ethnicity most of them were Brahmin $(38 \%)$ and Madhesi (31\%), and about $51 \%$ were working in

Table 1: Socio-demographic profile of study population $(n=260)$

\begin{tabular}{|llll}
\hline Characteristics & Category & Number & Percentage \\
\hline Age (Years) & $<20$ & 14 & 5.4 \\
& $20-29$ & 72 & 27.7 \\
& $30-39$ & 74 & 28.5 \\
& $40-49$ & 57 & 21.9 \\
Gender & $50+$ & 43 & 16.5 \\
\hline Religion & Male & 187 & 71.9 \\
& Female & 73 & 28.1 \\
\hline \multirow{3}{*}{ Occupation duration } & Hindu & 213 & 81.5 \\
in years & Muslim & 47 & 18.1 \\
\cline { 2 - 4 } & $10-19$ & 133 & 51.2 \\
Ethnicity & 20 and above & 72 & 27.7 \\
& Brahman/Chhetri & 99 & 21.2 \\
& Madhesi & 81 & 38.1 \\
& Muslim & 46 & 17.2 \\
& Janjati-terai & 16 & 6.2 \\
& Janjati-hill & 15 & 5.8 \\
& Dalit - hill & 3 & 1.5
\end{tabular}


According to table 2, while most teachers were well aware of basic aspects of swine flu but only $37 \%$ could tell swine flu is also known as $\mathrm{H} 1 \mathrm{~N} 1,65 \%$ could tell that swine flu is viral in origin, $86 \%$ thought that it is a preventable disease and $93 \%$ agreed that face mask could help in the prevention.
When we asked about the source of transmission of swine flu (Figure 2), most of them expressed that it can be transmitted by infected person (77\%) and consuming pork meat (34\%) and some also told that vector like mosquitoes (14\%) can transmit the swine flu.

Table 2: Knowledge about swine flu in the study population $(n=260)$

\begin{tabular}{|c|c|c|c|}
\hline Characteristics & Options/answers & Number & Percentage \\
\hline Heard about swine flu? & Yes & 260 & 100 \\
\hline \multirow[t]{5}{*}{ What is the other name of swine flu? } & Bird flu/H5N1 & 34 & 13 \\
\hline & H1N1 & 97 & 37.3 \\
\hline & $\mathrm{H} 2 \mathrm{~N} 2$ & 2 & 0.8 \\
\hline & SARS & 1 & 0.4 \\
\hline & Don't know & 126 & 48.1 \\
\hline \multirow[t]{4}{*}{ What is the Causative agent for swine flu? } & Bacteria & 20 & 7.7 \\
\hline & Parasites & 10 & 3.8 \\
\hline & Viruses & 170 & 65.4 \\
\hline & Don't know & 60 & 23.1 \\
\hline \multirow[t]{3}{*}{ Is breast-feeding protective against swine flu? } & Yes & 110 & 42.3 \\
\hline & No & 70 & 26.9 \\
\hline & Don't know & 103 & 39.6 \\
\hline \multirow[t]{3}{*}{ Availability of vaccine against swine flu? } & Yes & 87 & 33.3 \\
\hline & No & 70 & 26.9 \\
\hline & Don't know & 103 & 39.6 \\
\hline \multirow[t]{3}{*}{ Is Prevention possible? } & Yes & 224 & 86.2 \\
\hline & No & 20 & 7.7 \\
\hline & Don't know & 16 & 6.2 \\
\hline \multirow[t]{3}{*}{ Any role of facemask in controlling infection } & Yes & 242 & 93.1 \\
\hline & No & 11 & 4.2 \\
\hline & Don't know & 7 & 2.7 \\
\hline \multirow[t]{2}{*}{ Is isolation necessary? } & Yes & 215 & 82.7 \\
\hline & No & 45 & 17.3 \\
\hline
\end{tabular}

Most of them received information from Radio/TV (84\%) followed by newspapers (63\%). The only $7 \%$ had received information from health centre (Figure 1).

Figure 1: Distribution of respondents according to source of information (Multiple options) $(n=260)$

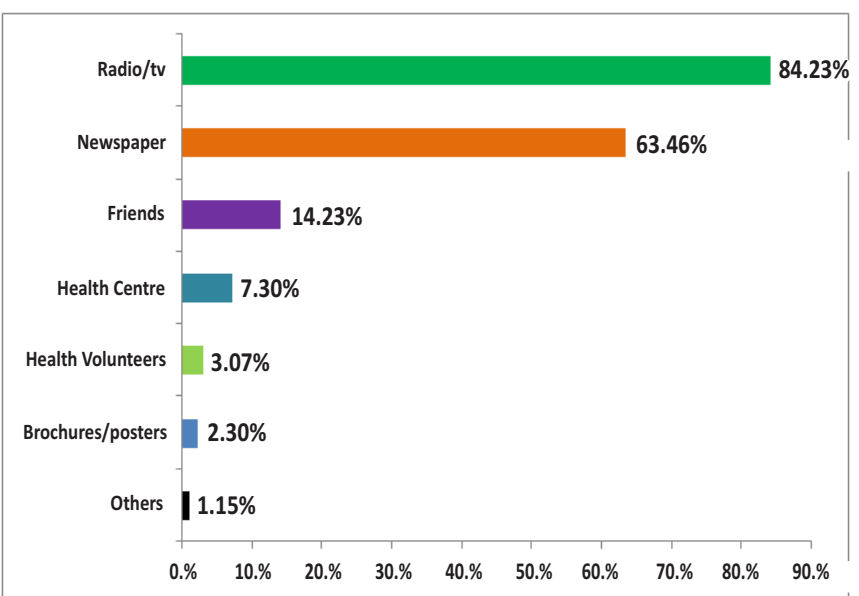

Figure 2: Distribution of respondents according to source of infection (Multiple options) $(n=260)$

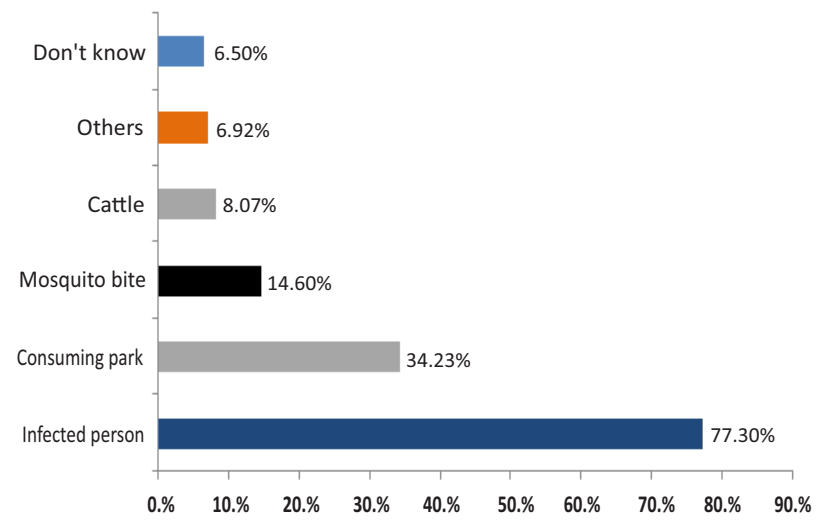

Figure 3 shows the knowledge about routes of transmission of H1N1, majority expressed that sneezing (90\%), touching contaminated surfaces (41\%) are major route of transmission, and some said the consuming pork meat is also one of the route of transmission. 
Figure 3: Distribution of respondents accordig to the knowledge about routes of transmission (Multiple options) $(n=260)$

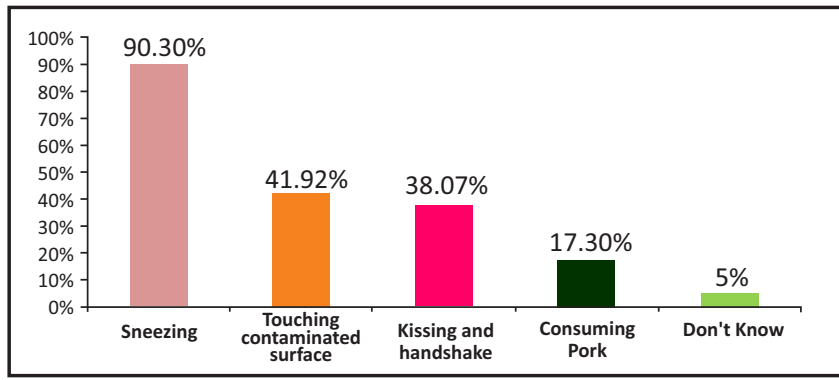

About $99 \%$ of the respondents thought that swine flu is communicable, and $95 \%$ thought that it is a life threatening disease (Table 3).

Table 3: Attitude about swine flu in the study population ( $n=260)$

\begin{tabular}{lccc}
\hline \multicolumn{1}{c}{ Questions } & Options & Number & Percentage \\
\hline Is swine flu communicable? & Yes & 257 & 98.8 \\
& No & 3 & 1.2 \\
\hline Is swine flu life threatening? & Yes & 246 & 94.6 \\
& No & 14 & 5.4 \\
\hline Worry about suffering from swine flu? & Yes & 193 & 74.23 \\
& No & 67 & 25.76 \\
\hline Daily life disturbed by swine flu? & Yes & 237 & 91.15 \\
& No & 23 & 8.84 \\
\hline Interested in knowing the ways to & Yes & 76 & 29.23 \\
prevent? & No & 184 & 70.76 \\
\hline Are protective measures sufficient? & Yes & 76 & 29.23 \\
& No & 184 & 70.76 \\
\hline Willing to take vaccine if present? & Yes & 243 & 93.46 \\
& No & 17 & 6.54 \\
\hline Are you afraid of the vaccine's adverse & Yes & 93 & 35.76 \\
reaction? & No & 167 & 64.23 \\
\hline Will you notify a suspected case? & Yes & 227 & 87.30 \\
& No & 33 & 12.69 \\
\hline Is available information sufficient? & Yes & 39 & 15 \\
\hline Mea sures ta ken by govern ment & Yes & 221 & 85 \\
sufficient? & No & 221 & 85 \\
\hline
\end{tabular}

About $94 \%$ of the respondents believed that maintaining good personal hygiene helps in prevention of swine flu; similarly, 95\% thought that avoiding crowded places and physical contact also helped in prevention of transmission (Table 4).

\section{Table 4: Awareness of practices regarding swine flu in study population $(n=260)$}

\begin{tabular}{|lccc|}
\hline Characteristics & Category & Number & Percentag \\
\hline Maintaining personal hygiene helps in & Yes & 246 & 94.6 \\
prevention? & No & 14 & 5.4 \\
\hline Extra care be taken for suspected cases? & Yes & 258 & 99.2 \\
& Don't know & 2 & 0.8 \\
\hline Closing schools during outbreak effective? & Yes & 189 & 72.6 \\
& No & 71 & 27.4 \\
\hline Avoiding crowded places/physical contact & Yes & 248 & 95.3 \\
effective? & No & 11 & 4.3 \\
& Don't know & 1 & 0.4
\end{tabular}

We try to compare between demographic variables with Knowledge, Attitude and Practice (Table 5), which shows that as the work experience increases, the knowledge increases, it was observed that females had better attitude $(p<0.023)$, towards preventive measures of swine flu as compared to the males, but males had better practices $(p<0.001)$ as compared to the females, however there was no statistically significant difference between gender regarding the knowledge of swine flu $(p=0.121)$. Likewise, Hindu were observed to have better knowledge $(p<0.001)$, attitude $(p<0.008)$ and practice $(p<0.001)$ regarding the swine flu as compared to Muslims

Table 5: Comparison between variables with knowledge, attitude and practice

\begin{tabular}{llll}
\hline Variables & $\begin{array}{l}\text { Knowledge } \\
\text { Mean } \pm \text { SD }\end{array}$ & $\begin{array}{l}\text { Practice } \\
\text { Mean } \pm \text { SD }\end{array}$ & $\begin{array}{l}\text { Attitude } \\
\text { Mean } \pm \text { SD }\end{array}$ \\
\hline Work Experience & & & \\
\hline$<10$ Years & $26.70 \pm 4.00$ & $37.67 \pm 5.00$ & $9.23 \pm 0.11$ \\
10 -19 Years & $27.08 \pm 3.67$ & $39.65 \pm 5.66$ & $9.31 \pm 0.20$ \\
$>19$ Years & $27.53 \pm 3.16$ & $39.76 \pm 4.65$ & $8.83 \pm 0.19$ \\
$p$-value & 0.435 & 0.159 & 0.007 \\
\hline Gender & & & \\
\hline Male & $27.21 \pm 3.71$ & $39.16 \pm 4.84$ & $9.03 \pm 0.35$ \\
Female & $26.40 \pm 3.87$ & $36.68 \pm 5.46$ & $9.49 \pm 0.63$ \\
$p$-value & 0.121 & 0.000 & 0.023 \\
\hline Religion & & & \\
\hline Hindu & $27.70 \pm 3.03$ & $39.09 \pm 5.00$ & $9.27 \pm 1.43$ \\
\hline Muslim & $23.30 \pm 4.57$ & $35.61 \pm 4.81$ & $8.65 \pm 1.46$ \\
$p$-value & 0.000 & 0.000 & 0.008 \\
\hline
\end{tabular}

After calculating the total score for knowledge, attitude and practices, in this research we have found that (Figure 4), most of the respondents (77.30\%) had good knowledge about swine flu. Similarly, 95\% were found to have a good attitude, however only $59 \%$ were practicing measures and precautions to prevent it.

\section{Figure 4: Perception about swine flu among study population $(n=260)$}

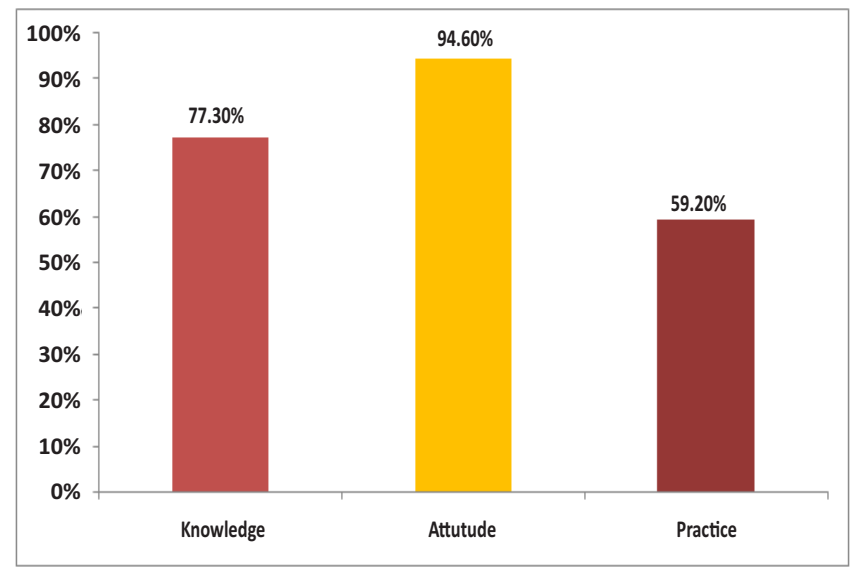




\section{DISCUSSION}

School teachers are active and important person of our society, they can influence population at large scale, as they are responsible for education and enlightenment of a large number of children and their parents and society. In spite of the rising incidence of swine flu amongst exposed population, only limited information is available for the knowledge, attitude and practices of school teachers. Good knowledge regarding swine flu amongst teachers will prove to be immensely helpful. Teachers good Knowledge, Attitude and Practice will not only benefit them but also translate into disseminating the same to students and their families resulting in maximum benefit to society. ${ }^{10}$

Knowledge of School Teachers: Majority of respondents had correct knowledge about basic aspects of H1N1 (causative agent, route of transmission and availability of vaccine) which was consistent with similar a study done in Pune, India. ${ }^{9}$ All the teachers were aware about swine flu but almost four out of ten could cited the scientific name of H1N1, most could cited that it is viral in origin, also, most of them thought that it is a preventable disease and $93 \%$ agreed that face mask could help in the prevention which was consistent with a study done in Hongkong. ${ }^{11}$

Attitudes of School Teachers:Almost all of the respondents thought that swine flu is communicable and is a life threatening, however, in another study respondents didn't regard it as life threatening. ${ }^{6}$ Ninety-one percent of the respondents had their daily life disturbed by the rising incidence of swine flu in the country, and $74 \%$ were worried about suffering from the disease themselves. About $70 \%$ of the people thought that the protective measures are not sufficient to protect the society from spread of the disease. Almost $93 \%$ were willing to take the vaccine against swine flu, had it been present. Almost $85 \%$ felt that the information that is made available to the public is not sufficient, and thought that government isn't doing enough to ensure protection and knowledge of the people.

Practices of School Teachers: Majority of the respondents believed that maintaining good personal hygiene helps in prevention of swine flu which was consistent with findings that $61 \%$ people perceived the efficacy of hand washing as very good. ${ }^{11}$ However, only $2.1 \%$ believed in hand washing as mode of prevention. ${ }^{12}$ Similarly, $95 \%$ thought that avoiding crowded places and physical contact also helped in prevention of transmission similar to the findings of $60 \%$ believed avoiding crowded places. ${ }^{9}$ About $72 \%$ of the respondents believed that closing the schools during seasonal flu outbreaks is a good idea and $99 \%$ thought that extra care should be taken for the suspected cases.

When compare with knowledge, attitude and practice which shows that with increase in work experience, the knowledge of swine flu were increased among respondents, it was observed that females had a better attitude towards preventive measures of swine flu as compared to the males, but males had better practices as compared to the females, however there is no statistically significant difference between gender regarding the knowledge of swine flu. Likewise, Hindu were observed to have better knowledge, attitude and practice regarding the swine flu as compared to Muslims. A study done by Balkhy HH et al 2010, ${ }^{12}$ reveal that education was the only significant predictor of concern, and the level of education was inversely related to the degree of concern $(p<0.001)$.

\section{CONCLUSION}

Most of the respondents had good knowledge about swine flu with good attitude but not good practice for prevention of swine flu. Majority expressed that sneezing was routes of transmission of swine flu. So concerned authorities should encourage them to practice proper measures to prevent the spread of disease.

\section{RECOMMENDATIONS}

Although there was good knowledge about swine flu and attitude but regarding practice there was not much concern for prevention of swine like hand washing as a preventive measure. So health education for behavioural changes a corner stone for a healthy life style that could be maintained through the future generations. A comprehensive health education program should be properly planned and implemented in schools using different approaches. Properly planned interventions for cost-effective positive achievements should be maintained through regular monitoring, supervision and periodic evaluation and highlights the potential of school as a promising venue for hand-washing promotion activities and lay foundations for behaviour change in long-term.

\section{LIMITATION OF THE STUDY}

The study included that the observations were based on perception about swine flu among school teachers; the findings of the study were for school teachers of government and private school and the study design did not include any controls. The study has not large sample size, so the results cannot be generalized.

\section{ACKNOWLEDGEMENT}

I would like to express my gratitude towards School of Public Health and Community Medicine, BPKIHS, Inaruwa Municipality, the school principals and teachers for giving us the consent for conducting our study. I would like to acknowledge my colleagues and MBBS batch 2012 for their never-ending support.

\section{CONFLICT OF INTEREST}

We declare that no competing interest. 


\section{REFERENCES}

1. Girard, M, Tam, J., Assossou, O. and Kieny, M. The 2009 A/H1N1 influenza virus pandemic: A review. Vaccine. (2010); 28(2): 4895-4902.

2. Center for Disease Control and Prevention (CDC). http://www.cdc.gov /flu/swineflu/h3n2voutbreak.html. (Cited: May 15, 2017)

3. Pandemic Influenza (H1N1)2009 update, 69.http://www.who.int /csr/don/2009_10_09/en/print.html. (Cited May 15, 2017)

4. Center for Disease Control and Prevention (CDC). "CDC Advisors Make Recommendations for Use of Vaccine Against Novel H1N1". Press release. https://www.cdc.gov/media/pressrel/2009/r090729b.htm (Cited May 15, 2017).

5. Rubin GJ, Amlot R, Page L, Wessely S. Public perception, anxiety and behaviour change in relation to the swine flu outbreak: cross sectional telephone survey. BMJ 2009; 339: 2651.

6. Joseph T.F. Lau A, Griffiths S, Chow Choi K, Tsui HY. Widespread public misconception in the early phase of the H1N1 influenza epidemic. J Infect 2009.

7. Akan H, Gurol Y, Izbirak G, Ozdatli S, Yilmaz G, Vitrinel A, Hayran O.Knowledge and attitudes of university students toward pandemic influenza: a cross-sectional study from Turkey.BMC Public Health. $2010 \mathrm{Jul}, 13 ; 10: 413$.
8. Swine flu: Some facts. https://bhattaraipradip.wordpress.com. (Cited May 15, 2017)

9. Bansal AS, Gupta RK, Gupta RR. Can good KAP amongst school teachers prevent H1N1 Influenza? A beginning. Journal of Evolution of Medical and Dental Sciences. 2014, Jan;3(3).

10. Meilicke G, Riedmann K, Biederbick W, Müller U, Wierer T, Bartels C. Hygiene perception changes during the influenza $A$ H1N1 pandemic in Germany: incorporating the results of two cross-sectional telephone surveys 2008-2009.BMC Public Health, 2013; 13. pp 959.

11. Balkhy HH, AbolfotouhMA, Al-Hathlool RH, Al-Jumah MA, Awareness, attitudes, and practices related to the swine influenza pandemic among the Saudi public.BMC Infectious Diseases 2010,10:42.

12. Sharma S,.Arora V.K, MahashabdeP.Knowledge And Behavior Regarding Swine Flu Among Interns At Index Medical College, Hospital \& Research Center, Indore (M.P.).Journal of Evolution of Medical and Dental Sciences, 2014 Mar,3(10). 